\title{
DO WE NEED A NEW PARADIGM? An Invitation to Reassess Business Education
}

\author{
MICHAEL J. GARANZINI, S.J. \\ Secretary for Higher Education, Society of Jesus \\ Fordham University, New York, New York, U.S.A. \\ mgaranzini@fordham.edu
}

The editors of the Journal of Management for Global Sustainability invited Fr. Garanzini to share the progress of a group that has recently begun reassessing business education in Jesuit business schools and, perhaps, even beyond. In this piece, he shares how and why the group came into being, what it has done so far, what it might do in the near future, and what implications its work might have for readers of this essay. This editorial concludes with the group's white paper entitled "An Inspirational Paradigm for Jesuit Business Education."

Faculty teaching in business schools today are well aware of the calls to reexamine the curriculum and goals of traditional undergraduate and graduate business education. Teaching business is a highly competitive enterprise, with changes in the way business education has been conceived and delivered, especially at the graduate level, having undergone significant assessment and re-assessment over the past two decades. Any number of alternatives to the traditional package of MBA courses is now available. Programs differ by emphasis-some teach discipline-based knowledge and skills while others stress leadership and interpersonal competencies-and methods of instruction and learning vary from place to place.

Critics argue, however, that the standard program of instruction in business education is almost universally based on fundamental assumptions that have supported a harsh and often unjust economic model in general. Our present economic and financial systems, and therefore of business itself, are based on a false reading of human nature (the person-as-consumer) and exacerbate some of the most pressing problems facing society and the global order today.

A group of leaders in Jesuit business education, calling themselves the "New Paradigm Group," thus set out over a year ago to tackle the following questions: 
Should a Jesuit business school offer students an alternative vision to the present economic order and the way business is usually conducted? Is there a moral and practical imperative to reconsider the fundamentals of business education in light of factors such as the stress of pollution, depletion of resources, growing income gap between and within nations, and violence and displacement that seem to be overwhelming the capacity of democratic societies to cope with such?

Students themselves, especially some of the brightest and most engaged, are also asking for something other than what we are giving them in our standard fare. One academic leader in a top business program observed, in fact, that many of the brightest and most entrepreneurial students do not want to attend a business school. She noted that they would rather get a degree in the arts and sciences colleges where they feel challenged and heard.

Fortunately, the educators raising an alarm are not alone. Corporate leaders have spoken out recently about the challenges to "business as usual" and have called for an examination of the fundamentals upon which our economic system is based. Groups like the Business Leadership Roundtable, for instance, with a membership consisting of the largest and most prominent business and financial corporations around the globe, have admitted that the present world situation is unsustainable.

Economists, too, like Joseph Stiglitz, to name but one, have warned for some years now that the world economy must re-think the rules on which it operates, rules which have been stacked in favor of the haves. The gap between rich and poor in nations like the United States continues to widen; indeed, income inequality in many parts of the world is eroding democracy. Depletion of our basic resources augurs a crisis ahead if we do not rethink how we will manage them and their distribution. Many of these economists also argue for more government management of the economy. Yet, as some say, we all know that governments listen to business and that business leaders are produced in our business schools.

One of the leading voices for change on the world stage, however, is not that of an economist. Pope Francis has carefully and forcefully articulated both the questions about and urgent need for change in the economic and financial spheres. His encyclical Laudato Si' (Francis, 2015) pressed the case for fundamental change but, more importantly, made the point that the involvement of corporate and 
economic leadership is not enough. The Pope stressed the role of every human being on the planet, calling for a fundamental change in the way we approach caring for our common home. His call for a united effort to address the ills confronting our planet was based on a century's worth of social teachings which had a deep and rich philosophical grounding based on principles such as the dignity of every human person, their rights to a decent opportunity to support themselves, and our obligations to weigh the distribution of resources in light of the "common good." Like other leaders, the Pope pointed to the need for urgent action and also called on young people, whose voices are becoming louder and louder, to spur their elders to it.

Over the course of twelve months, the New Paradigm Group discussed the depth of the challenges facing business in the future. They debated the question of responsibility on the part of business schools to address the crisis and how to encourage reform efforts in Jesuit business institutions. They consulted with business and corporate executives, economists, and academic leaders from a variety of institutions who are attempting programmatic change in light of some of the fundamental flaws of the present neoliberal economy. They then set out to put their ideas on paper.

The result of this effort is the essay entitled "An Inspirational Paradigm for Jesuit Business Education." Its aim is to present the group's rationale for curricular reform and seed a discussion among faculty members of Jesuit business schools regarding how best to incorporate a new vision of what business "ought to be" in business school curricula. The paper was also designed to reflect on what educators are hearing from their brightest students, those who are likely to shape tomorrow's economy, its business and financial enterprises, and, thus, our political and social institutions.

The new group, whose names are appended to their paper, is well aware, however, that not all faculty believe that the liberal economy needs fixing, that "things are actually broken." Some faculty, in fact, firmly believe that it is important to keep a steady course, that there may even be a need for some minor reforms that enable the system to perform better, with more or perhaps less regulation from government and international agencies. Those skeptical of the need for reform, after all, argue that the way the global economy has operated has brought about not only tremendous individual wealth to unprecedented numbers of people but 
also improved life-expectancy, access to education, and social mobility for many of the poor.

The voices of disagreement on the need for change, therefore, must also be heard. The group's paper thus calls for discussion and debate; indeed, more than that, it is an opportunity for in-depth reflection on and experimentation in business education in ways that go beyond the reforms of previous generations. Method and format are important but so too is content and, even more critically, a re-examination of the assumptions built into our current business programs. It is essential, no doubt, to review the economic and finance assumptions of the neoliberal economy. What we need is something to inspire hope that business can assist in saving the planet and, in doing so, free our social lives from excessive greed and indifference to suffering.

While this "white paper" was written with Jesuit business school faculty in mind, it is also a call for business schools of all stripes to re-examine their core product in the light of present and future challenges. It assumes a Roman Catholic social teaching lens because that is the clearest and most well-developed body of social thought that has taken concerns about the present economic paradigm seriously, offering a sustained and respected critique of laissez-faire economic policies, proposing an alternative reading of the human situation, and upholding the "common good" as a necessary antidote to the harsher aspects of said policies. The thought piece interprets the present situation, citing both positive and negative trends, and recognizes a shift in, and gives special attention to, the hopes and concerns of younger people who will be living with the structures we create today. Lastly, it offers four guideposts related to curricula, pedagogy, leadership skills, and stakeholders for the project ahead-the meaningful reform of business education at all levels.

\section{NOW WHAT?}

Before we turn to the white paper, however, what next steps are envisioned? The group is now canvassing deans and academic leaders in Jesuit business schools more broadly in the hopes of encouraging and promoting a sustained conversation as well as curricular and program reform projects in the coming academic year and beyond.

Such a conversation needs the support of school leadership. Members of the faculty, regardless of their particular disciplines, are also encouraged to discuss 
and debate how business education can change so it can prepare a new generation of business leaders. New courses in economics, finance, and the general business curriculum need to be fashioned based on a paradigm grounded in more humane and socially conscious principles such as those articulated in documents like Laudato Si'.

Our hope, then, even though this initiative is led at present by individuals associated with Jesuit business schools and directed toward education in those institutions, is that faculty in all business schools will be encouraged to engage in similar inquiries if they are not already doing so. We hope that what we are doing will be helpful to others in similar institutions and that we learn from other business schools that have an interest in revamping their own curricula. Indeed, we believe that all business education, Jesuit or otherwise, needs to be aligned with the realities and challenges of the $21^{\text {st }}$ century, and that bringing about this realignment will require all of us to play a contributing role.

Speaking directly to young people who will create and manage the economies of the future, the Pope wrote: "We are not faced with two separate crises, one environmental and the other social, but rather with one complex crisis that is both social and environmental." Strategies for solving the pressing problems of today and tomorrow thus "demand an integral vision to combating poverty, restoring dignity and at the same time protecting nature." These are words that can guide the reform effort.

\section{AN INSPIRATIONAL PARADIGM FOR JESUIT BUSINESS EDUCATION}

\section{The State of Affairs}

Business is a noble vocation, directed to producing wealth and improving our world. It can be a fruitful source of prosperity for the areas in which it operates, especially if it sees the creation of jobs as an essential part of its service to the common good. (Francis, 2015: no. 129)

Despite significant global economic progress in recent decades, extreme poverty and environmental degradation continue to persist. Far too many lack access to the goods and services that are essential to survive and thrive, including nutrition, healthcare, education, decent jobs, clean water, sanitation, affordable housing, and clean energy. It is tragic, moreover, that those on the margins-women, children, 
minorities, migrants and refugees, and indigenous communities, among otherstypically find themselves most excluded from the benefits of the market economy; indeed, inequality in income and wealth remains high both within and between countries, and is even increasing in some instances.

The nature of work, too, is rapidly changing. Outsourcing, artificial intelligence, and automation, for instance, are replacing work formerly done by human beings. Labor market disruptions such as these can feed into rising inequality as more and more workers face futures full of anxiety, for while technological progress can provide widespread societal improvements, these gains accrue all too often to those at the top.

The Jesuit university, with the Jesuit business school in particular, can be, as J. Matthew Ashley extrapolates from Pope Francis's writing, an instrument of mercy that provides a powerful impetus to action for understanding the world and changing it (Ashley, 2018). Universities, along with undergraduate and graduate business schools in particular, play a crucial role as such in addressing these challenges and building opportunities for positive change. Their responsibility at a minimum is twofold:

- generate new knowledge, through research, that informs and transforms the way business is conducted, and

- raise awareness to help provide a framework for reflection on the role each student plays in being part of the solution while supporting students and faculty as they develop concrete ways in which they can become part of the solution to these challenging issues.

We must not be naïve about the complexity of these challenges. The fact that the world is more interconnected than ever before often provides incredible opportunities for making both positive change and lasting destruction. The fourth industrial revolution is proceeding at a dizzying pace, with some having referred to this time as a "VUCA" moment—a moment characterized by volatility, uncertainty, complexity, and ambiguity. This makes the reform we need even more of an imperative and yet harder to achieve. 
Business faculty across the globe are thus engaged in research that impacts the way business is conducted. Accreditation bodies are including the recognition of societal impact in their standards to which business schools must adhere, and recent statements of the Business Roundtable ${ }^{1}$ that put aside the shareholder primacy model are also encouraging. "Each of our stakeholders is essential," the Roundtable concludes, "[and] we commit to deliver value to all of them, for the future success of our companies, our communities, and our country" (Business Roundtable, 2019a, 2019b). The movements for sustainable development, just resource allocation, and humanistic management practices and policies, along with growing sensitivity toward the effects of business practices on the quality of life and potential of local communities, make us confident that business may be the surest and best hope for addressing the urgent problems of our day. The corporate social responsibility movement has indeed affected businesses of all sizes, with other movements such as the triple bottom line, Global Reporting Initiative, and United Nations Global Compact with Business calling attention to the fact that we can no longer continue to do "business as usual."

With corporations throughout the world changing the way they do business, and shifting what they measure and report as elements of business performance, organizations like the Sustainable Accounting Standards Board are creating frameworks for reporting such metrics. The OECD Guidelines for Multinational Enterprises (OECD, 2011) and the UN Guiding Principles on Business and Human Rights (United Nations, 2011) also provide important frameworks that can be incorporated into business school curricula, with additional context provided by the statements of the Business Roundtable that put aside the shareholder primacy model (Business Roundtable, 2019a, 2019b).

\section{Hungers}

This shift links directly to what our students have been and are still demanding for. We believe that what motivates them at the deepest level are what we might call "hungers" or "desires" that drive and inspire their idealism and sense of hope. They need to be equipped with the skills to survive in today's economy yet they also yearn for integral human development, that is, the development of the whole person. 
These desires which Jesuit business education hopes to stir and to meet are hungers for the following:

- Integrated Knowledge. Students today appreciate having so much information at their fingertips yet they long for a more robust formation that not only integrates their intellectual, affective, and volitional capacities but also helps them to reach a greater depth of understanding through an appreciation of how varied subjects and disciplines fit together.

- A Moral Compass. They also experience the limitations that accompany a moral discourse focusing almost exclusively on individual rights while almost ignoring the responsibilities we have for each other. Our students are not looking for recipes; rather, they display a desire for an ethical foundation and method for moral discernment.

- Community. Students today value the building of meaningful communities with genuine connectedness and which incorporate engaged civility. They display a new strength of passion and commitment to use their gifts and talents for others. Having a sense among themselves that they have found their voice as change agents, they now long to participate more actively in creating more good in the world.

- A Global Paradigm. Having seen the limitations and dangers of ethnocentrism and even of nationalism, our students want to embrace a more cosmopolitan perspective. They see very clearly that each of us dwells in many communities, from the community of our birth to the community of the human family, and they believe that we have duties to each of them.

- An Adult Spirituality. Tired of the polarizing debates, our students long for a spirituality that sustains and empowers, one where there is ample room for both faith and reason that give meaning to their lives. 
- Dignified Work and Meaningful Impact. Work is not just about earning a living; in the words of Pope Francis, it is also "part of the meaning of life on this earth, a path to growth, human development and personal fulfilment." Young people today have a greater appreciation for this dimension of work. There is a desire to share and spread positive change, which drives the interrelated need for communication, diplomacy, integrated thinking, and collaboration.

- Experiential Learning. Jesuit business schools must adapt their pedagogy to the learning styles of our $21^{\text {st }}$-century students while remaining grounded in an Ignatian approach that emphasizes the learning process (context, experience, reflection, action, and evaluation). Student learning outcomes are enhanced as well by immersive experiences and live cases.

\section{An Inspirational Educational Paradigm for Jesuit Business Schools}

To respond to these deep hungers in the light of our present context, we need a renewal of Jesuit business education. This implies a new approach to shaping the leaders we need at a complex moment in history, all with the aim of creating a just social order in which all can flourish. We have a responsibility not only to reshape our curricula but also to touch our students' hearts and minds so that they can be a light to the world as well as use their skills and talents to address the grave challenges facing us all. While individual faculty members and schools have made progress, business education, by and large, has not systematically made this essential shift.

This new educational paradigm has a number of elements to make it relevant, effective, meaningful, and truly Jesuit. They are as follows:

- $\quad$ Renewing business curricula. A new curricula that follows this paradigm would be developed in light of insights from Roman Catholic social teaching and would encompass anthropology, ethics, corporate social responsibility, governance, sustainability, and an understanding of the current social reality. While embracing the efficacy of the market economy, it would stress that economic activity must serve the common good especially by meeting the 
needs of the poor and excluded. It would emphasize, in addition, that all private and public economic activity must be based on environmentally sustainable practices.

- Use of the Ignatian pedagogical paradigm. Ignatian pedagogy recognizes the importance of context, experience, reflection, action, and evaluation. Research reinforces the importance of this approach, along with the essential role of immersive and community-engaged learning. The Ignatian paradigm is one of holistic formation that seeks to inculcate the right attitudes and values in our students based on the premise that "becoming" is more important than simply "knowing." A "co-curricular" component, therefore, that includes direct contact with the poor and excluded is central.

- A vision of the skills needed for this new kind of leadership. Jesuit business education, which must build on the important foundations of the humanities and technical education, must also include the skills necessary for a new kind of leadership whose proponents are formed in ways that allow them to view uncertainty and ambiguity as opportunities, relying on creativity, communication, and storytelling as important capacities for bringing about positive change. Such leaders must, at the same time, see leadership as an opportunity for serving others and the common good.

- $\quad$ The role of key stakeholders. The effort toward the realization of this vision involves faculty, alumni, and the broader business community. Jesuit business schools must engage and inspire faculty to develop and deliver these new business alternatives while both research on the impact of these changes and the teaching of these new concepts must become widespread.

A Jesuit education in business is based firmly upon an ethical framework that emphasizes the fundamental questions about the dignity and potential of the individual, the centrality of the common good, and the importance of social networks that affirm and support human flourishing. Each academic field-marketing, finance, accounting, management, human resources, etc.--should offer an alternative vision 
based on ethical principles and the promotion of virtue as it acknowledges that the present approach to business education, with its emphasis on the profit motive while neglecting social good, contributes to an unsustainable economy that does not support human flourishing. What is best, both for all and for the planet? It is the responsibility of every faculty member, department, and school to articulate their position vis-à-vis the Ignatian paradigm. Now is the moment for business education to respond to this critical challenge.

\title{
NEW PARADIGM GROUP TASK FORCE MEMBERS
}

\author{
Donna Rapaccioli \\ Dean, Gabelli School of Business, Fordham University (USA) \\ Task Force Chair \\ Paul Almeida
}

Dean, McDonough School of Business, Georgetown University (USA)

Rodolfo Ang

Dean, Graduate School of Business, Ateneo de Manila University (Philippines)

José de la Cerda

Dean, School of Business, DEAM/ITESO (Mexico)

Joseph Christie, S.J.

Dean, Academics, Xavier Institute of Labor Relations (India)

Josep Franch

Dean, ESADE Business School (Spain)

Michael Garanzini, S.J.

Secretary of Higher Education, Society of Jesus (Italy)

Patricia Grant

Senior Associate Dean for Undergraduate Programs

McDonough School of Business, Georgetown University (USA)

François Kaboré, S.J.

Director, Jesuit University Institute at the

Center for Research and Action for Peace (Ivory Coast)

Joseph Phillips

Dean, Albers School of Business and Economics, Seattle University (USA)

Michael Pirson

Faculty, Gabelli School of Business, Fordham University (USA)

Nicholas Santos, S.J.

Faculty, Heider College of Business, Creighton University (USA) 
Cristina Gimenez Thomsen

Director of Identity and Mission

Professor, Dept. of Operations, Innovation, \& Data Science

ESADE Business School (Spain)

Pedro Walpole, S.J.

Director of Research, Institute of Environmental Science for

Social Change (Philippines)

Augusto Zampini, S.J.

Director of Development and Faith

Dicastery for Promoting Integral Human Development (Vatican City)

\section{REFERENCES}

Ashley, J. M. 2018. The Jesuit university as an instrument of mercy. Jesuit Higher Education: A Journal, 7(1): 5-16.

Business Roundtable. 2019a. Business Roundtable redefines the purpose of a corporation to promote "an economy that serves all Americans." Available at https://www.businessroundtable.org/business-roundtable-redefines-the-purposeof-a-corporation-to-promote-an-economy-that-serves-all-americans.

Business Roundtable. 2019b. Statement on the purpose of a corporation. Available at https://opportunity.businessroundtable.org/wp-content/uploads/2020/04/ BRT-Statement-on-the-Purpose-of-a-Corporation-with-Signatures-UpdatedApril-2020.pdf.

Francis. 2015. Laudato si': On care for our common home. Vatican City: Libreria Editrice Vaticana.

OECD [Organisation for Economic Co-operation and Development]. 2011. OECD guidelines for multinational enterprises. Paris: OECD Publishing.

United Nations. 2011. Guiding principles on business and human rights. New York \& Geneva: United Nations Human Rights-Office of the High Commissioner. 
Michael J. Garanzini, S.J., is Secretary for Higher Education for the Society of Jesus (Jesuits) and chairman of the Board of Directors for the International Association of Jesuit Universities (IAJU), which consists of over 200 higher education institutions across the globe and includes over 50 business schools. Before becoming Secretary for Higher Education in 2012, Fr. Garanzini was president of Loyola University Chicago for 14 years and served in various academic posts at Georgetown University, St. Louis University, and the University of San Francisco. He has also served on a number of university and community boards and has taught courses in child and family psychology and therapy at the institutions where he served as both an administrator and faculty member. His academic field is in systems and attachment theory. 